\title{
THE EARLY CHRISTIAN BURIAL SITES AND THE TÜRBE OF IDRIS BABA
}

\author{
Róbert MAJOR ${ }^{1}$, Balázs KóSA², Tamás MOLNÁR ${ }^{3}$ \\ University of Pécs, Faculty of Engineering and Information Technology, Department of Visual Studies, Pécs, \\ Hungary \\ ${ }^{1}$ major.robi1192@gmail.com \\ ${ }^{2}$ kosa.balazs.84@gmail.com \\ ${ }^{3}$ tmolnar@pmmik.pte.hu
}

\begin{abstract}
The city of Pécs was already an important commercial and religious centre in ancient times. Because of the city's location, it has become one of the most important cultural hubs in Central Europe. In Pécs, in various historical times, many different cultures have flourished and one of the most typical imprints of these cultures are cemeteries and burial buildings. The subject of our research is to compare Idris baba's türbe with another iconic heritage of Pécs, the Early Christian Cemetery, furthermore as an example of this cemetery's visitor centre, designing a plan that reattaches the neglected Turkish cemetery to the city's life.
\end{abstract}

Keywords: monument, turkish, Pécs, downtown, türbe.

\section{Introduction}

In today's shrinking world, it is increasingly characteristic of cities that different cultures are mixed together. This phenomenon can acutely be felt in Hungary. The country lies on the border of East and West and belongs to both. During its history, the Carpathian Basin sometimes was under the influence of the East, at other times the West. In Hungary there is a unique built environment where western-style buildings can be found, but there are also oriental influences. The city of Pécs is also extremely interesting in this aspect. The most symbolic example of this is the mosque of Gázi Kaszim Pasa (Figure 1.), as there is a cross on its top with a crescent moon foundation, representing the duality of the building as a Christian temple and a Turkish mosque.

The monuments of the city give a distinctive atmosphere to the entire town, so it is especially important that we treat these buildings with due care and expertise. There are monuments in the city that are hidden from the ordinary man's eyes. One example is Idrisz baba's türbe from the Turk-

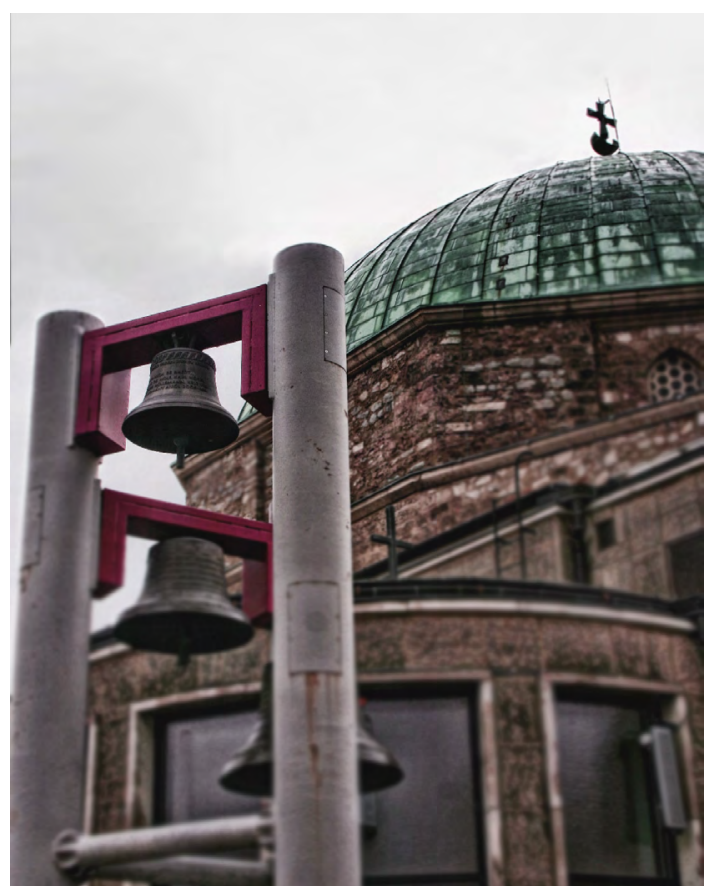

Figure 1. Mosque of Gázi Kaszim pasa 
ish occupation, which is one of the two remaining Hungarian türbes.

This is why we chose it as the topic of our research. Our goal is to showcase and engage a building in urban life, similarly to the architectural history of the Cella Septichora Visitor Center. That is why we compare ancient Christian and Turkish buildings, and then we propose through an architectural design a future of the türbe and its environment. The fact, that the türbe is located in a part of the city where all age groups turn up in large numbers in everyday life, makes it necessary for us to deal with it.

\section{Historical review and comparison}

\subsection{Burial in Pécs}

The area around Pécs has been inhabited since ancient times, so it is not surprising that there is and always have been many cemeteries in the city. In some parts of the city, as time passed, the Romans, the Huns, the Hungarians and the Turks were buried. The burial habits of different cultures and religions have left a unique impression on the city. The cemeteries were usually located at the edge of the city, as the city grew, they moved further and further away.

\subsection{Ancient christian cemetery [1]}

In ancient times, Pécs was named Sopiana and its history dates back to the second century AD. It was founded at the southern foot of the Mecsek Mountains at the juncture of the North-South trade routes. After 293, as the most prominent city of Southern Transdanubia, it became the administrative center of Valeria, which was one of the three territories of the province of Pannonia. The Romans, who arrived here, brought with them their culture as part of their daily life. At the same time, early Christianity began to gain ground from the south, so a strange mixture of the two cultures emerged with the populace slowly becoming Christan.

The image of the Early Christian Cemetery probably has traditionally been a reflection of the empire's widespread customs: cremation, gravestone, pagan cemetery attachments. But as time passed, Sopianae became filled with beautifully painted tombs under the buildings. The discovered memories are both architecturally and artistically unparalleled works that have been part of the UNESCO World Heritage since 2000.

\subsection{Idris baba's türbe [2]}

A lot of stories have circulated about Idris baba, some thought he was a doctor, others were writing about him, as a warrior monk (bektashi dervish). There are several legends about the saint, who has been buried on the Rókus hill in Pécs. The two great Turkish historians, Ibrahim Pecsevi and Elia Cselebi, were the first to mention him. They both wrote about the saint and his grave, but Ibrahim's account seems to be more credible. Idris baba's türbe (Figure 2.) has performed a variety of functions over the centuries. It was used, as a chapel, a hospital, a gunpowder and a bandage warehouse, until finally discovered in the last century and put under protection as a monument. At this time rebuilding and research began. In the 1960s, archaeological excavations were carried out in the area and in the building, including a full-scale structural survey. Interestingly, archaeologists have found no signs of other constructions in the neighbourhood, which is odd, because buildings of this type were built as monasteries or other building complexes.

The building is a stone structure, covered with an eight-sided dome. Its walls are not plastered because they have not found suitable patterns for restoration, so the transformations of the various ages can be observed.

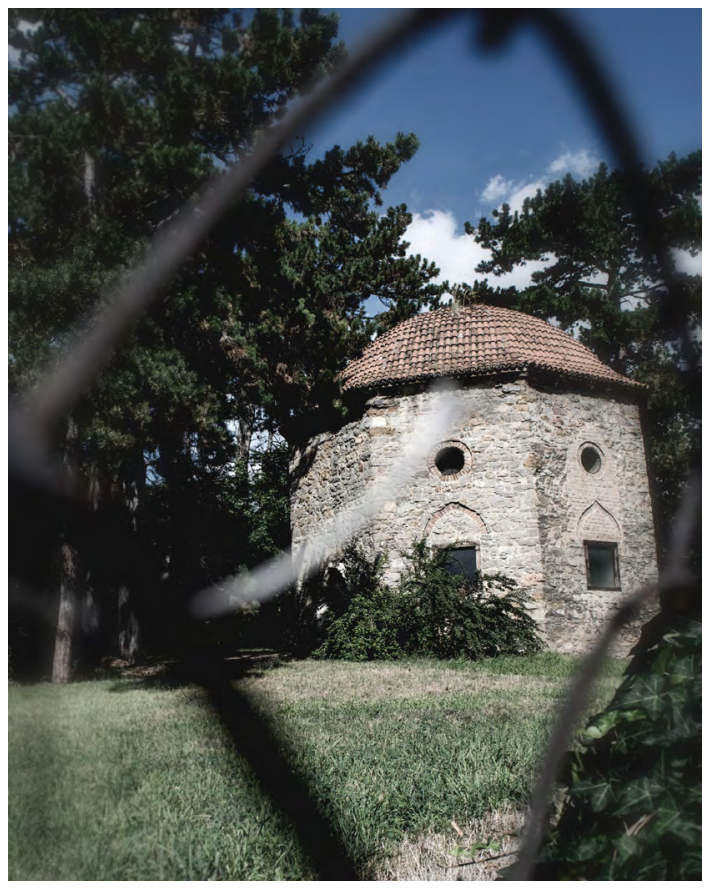

Figure 2. Idris baba's Türbe 


\subsection{Comparison}

It may be strange to draw a parallel between these two types of burial places, as they come from different ages and different cultures. It is, however, particularly interesting that these two cultures, independent from each other, have created similar buildings from the local materials. The ancient Christians burial chambers reflect the antique culture while the türbe is based on the traditions of the Near East and the nomadic peoples. And it is noteworthy that in Pécs, although centuries have passed, these remains are still concentrated in a narrow area.

\section{Plan presentation}

Idris baba's türbe is now separated by a fence from the hospital and from Nyár Street. One of the reasons is that a supporting wall at Nyár Street has to be replaced, due to the water flowing from the Mecsek. The essence of my plan is to restore this obsolete architectural memory to the everyday life of the city. For this to be possible, we have designed a public park where green areas and overlaid spaces fit into a resting park and create a smaller space around the türbe so that accessibility and presentation will also be easier. We have shaped the main directions of the park to the sides of the turf so that we can get a shifted central space whose centre is the türbe itself. We want to solve the isolation from the street by opening and transforming the supporting wall. The supporting wall we are planning to construct is a modern concrete wall where the openings are positioned so that they do not interfere with the drainage, yet make the monument visible and easy to access. At the height of the supporting wall, it follows the terrain and it is related to it everywhere. (Figure 3. and Figure 4.)

The park was inspired by Islamic burial habits and Muslim cemeteries. The paths outside the main directions of the park were inspired by a traditional Islamic motif (Rub el Hizb: indicates the end of each chapter of the Koran), and was constructed into a raster. Along these paths, water, as one of the strongest religious symbols and the symbol of purification, appears from time to time, coming into view at the beginning of the main route and in the pools next to the türbe, that symbolize the essential cleansing bath of Muslim rituals. In the green areas, we have used

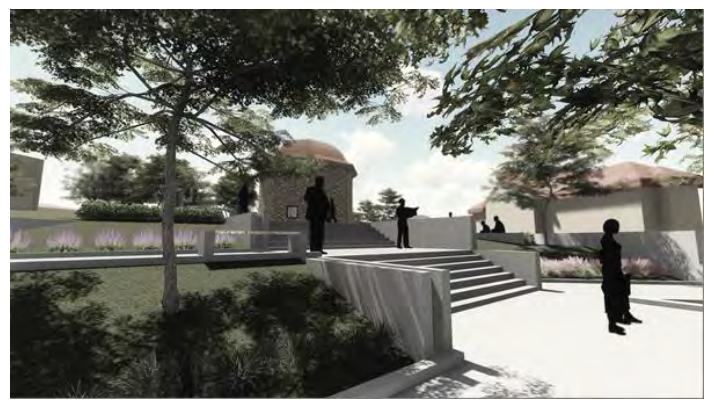

Figure 3. Visualization of the redesigned park

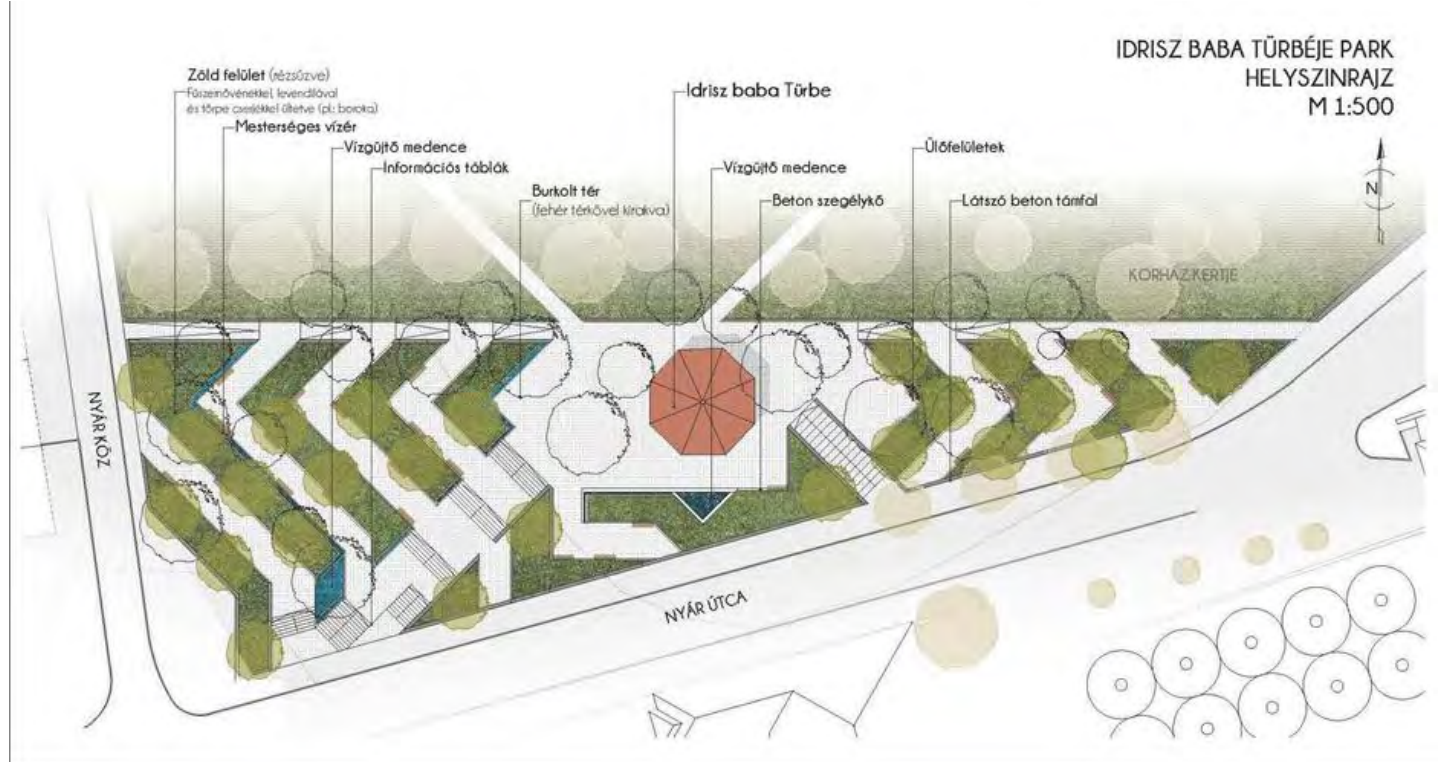


herbs, such as rosemary and laurel, and dwarf evergreens and other fragrant plants (lavender, jasmine). This is because in the Muslim rejuvenation, the body is rubbed with plants and essential oils till this day. It is also a good choice for this vegetation, as the neighbouring Pécs brewery sometimes releases a typical smell. Thus, fragrant plants refresh the surrounding air. Unfortunately, the present bigger trees are pine trees that can not survive the construction work, mainly the groundwork, so we decided instead to plant new trees. When choosing the tree species we have also kept in mind the afterlife and the passing, which, like the tomb, the türbe symbolizes, so we would recommend plants like cypress trees and pine trees, perhaps smaller leafy trees, fig trees and silkworms. Because of its symbolic value, ginkgo biloba (ginko biloba is believed to be an immortal member of the flora, attributed to wisdom and health in the east, also the symbol of division and unity). The pavement of the square and the roads is made of white stone. This color originated from the Muslim cemeteries. The issue of shading can be secured with temporary white canvas shrouds, until the trees have grown, which reinforces the parallelism of Muslim burial.

The area in question lies in a location that is one of the most popular routes used by the students of Pécs, as it is one of the shortest paths between the university's various branch buildings. Because of this, there are several restaurants and pubs in the area. But this is not the sole reason for the road being busy; this part of the city is home to the new building of pediatrics, obstetrics, ophthalmology and oncology. By transforming the environment of the türbe, a park could exist where students can relax, and those arriving for medical care find a more pleasant atmosphere.

\section{References}

[1] Hudák K., Nagy L.: Örökség füzetek 6. Nemzeti Kulturális Alap, Pécs, 2009, 9-62

[2] Sudár B.: A pécsi Idrisz baba-türbe. Forster Gyula Nemzeti örökséggazdálkodási és szolgáltatási Központ, Budapest, 2013, 43-67. 